\title{
Urban planning guidelines for a low carbon society: focus on urban transport
}

\author{
M. Taniguchi ${ }^{1}$, K. Kodama ${ }^{2} \&$ T. Fujii ${ }^{3}$ \\ ${ }^{1}$ Graduate School of Systems \& Information Engineering, \\ University of Tsukuba, Japan \\ ${ }^{2}$ Nikken Sekkei Research Institute, Japan \\ ${ }^{3}$ Department of Regional Policy, Tottori University, Japan
}

\begin{abstract}
Realization of a compact urban structure with a low transport environmental load to achieve a low carbon society has persisted as a critical social issue. Results of studies have confirmed repeatedly that a deep relation connects residential density and transport loads on the environment. Moreover, a relation between residential environments and transport loads has already been clarified in areas for which inhabitant transport activity data are available. However, the information obtained to date is insufficient for local administrators and local residents to be involved extensively in constructing a low-carbon-type urban structure. Specifically, urban planning guidelines must plainly present information of various types.

Based on the consciousness of the problem described above, this paper presents a proposal for urban planning guidelines that aggregate statistical information related to 1,996 detailed areas and the transport activities of 57,243 people. In the proposal, securing usability and generalization is addressed through the lateral collaboration of researchers in fields related to urban structure reformation, such as transport planning, urban design, and geography. The prepared guidelines were actually used in communications with local government representatives: their usefulness was demonstrated.
\end{abstract}

Keywords: low carbon society, compact city, guideline, land use. 


\section{Introduction}

It is well known that a compact urban structure reduces the environmental load from transport and thereby supports achievement of a low carbon society. However, policies to achieve that goal have not been implemented sufficiently; consequently, transport-related environmental loads have been increasing in recent years (Taniguchi et al. [1]). At the same time, methods to improve urban structures through effective reduction of the transport load in the field of urban and local planning have come to the fore as a critical issue (Echenique et al. [2]).

To address these issues, by statistically analyzing transport activities of inhabitants in residential areas, we have clarified the relation between characteristics of places of residence and transport environment loads at both city and town scales (Taniguchi et al. [3]). Based on that information, to promote detailed establishment of a low carbon society at a residential level, we published city planning guidelines for professionals (Taniguchi et al. [4]). Nevertheless, because no easy-to-understand information for administrative personnel and citizens in general has been offered to date, sufficient policies cannot be realized easily using such detailed guidelines alone. Based on that background, in this paper, we consider and propose a simple guideline index that is easy-tounderstand and which has scientific validity, such that people with no professional knowledge can understand the importance of urban compactness and use this knowledge as a trigger to participate in the realization of appropriate policies and measures.

\section{Required simple guidelines}

As to whether a compact urban structure can be realized, urban planning personnel in local governments have a great role that does not differ markedly among countries. Since urban compactness policies were proposed as a basic policy in Japan in July 2007, we have investigated the consciousness of compact city maintenance centring around 936 urban planning personnel of 130 local governments (prefectural and city governments, municipalities). Results show that, regarding the "feasibility of a compact city", the average score is only 1.7 on a five-grade evaluation, where 5 is feasible and 1 is infeasible. Even urbanplanning related personnel in local governments have professional knowledge that realizing a compact city is difficult. However, it is also apparent that a onehour lecture on basic related knowledge improves the average score to 3.8 .

The greatest obstacle to be overcome is "lack of comprehension of citizens": urban planning personnel in local governments believe that a compact city is difficult to realize. Many opinions are submitted that "objective effects are hard to explain" when a compact city is to be maintained. In other words, citizens in general must understand basic and objective information such as the degree of transport environment loading to be expected according to the type of residence and how much the transport environment load varies according to differences in 
characteristics of the district. Therefore, simple guidelines or indexes are necessary for citizens in general-not for specialists. Such information must satisfy requests in a readily comprehensible manner.

\section{Concept for preparing simple guidelines}

Even if guidelines are simple, their scientific validity must be secured. Consequently, the simple guidelines proposed herein are prepared by aggregating the scientifically valid contents of detailed guidelines used by specialists. When preparing the detailed guidelines, using search results on transport activities and district characteristics of 57,243 inhabitants living in 1,996 various residential areas having different characteristics of urban areas, residential areas are classified in consideration of statistical meaning. Specifically, as discrimination indexes, indexes of six kinds are used: 1 type of city (local region or large city area, or central city), 2 land use regulations (usage, distinction of low-rise or mid-to-high rise), 3 residential density, 4 distance from the city core, 5 distance from a station, and 6 the number of trains to the nearest station. As a result, residential area type settings of 129 types can be assigned in all. In this paper, by combining these characteristics with residential area types having a similar level of low carbon usage, aggregation into 10 types can be performed. When aggregating from detailed guidelines into simple guidelines, not only is a numerically similar environmental load amount adopted; a judgment is added from the standpoint of similarity of structures built there and the geographical, comprehensive, and global standpoint, such that the infrastructure development level is assessed for the district.

Here, 10 kinds are selected because, just as Mohs hardness adopts 10 stages to represent hardness of minerals, when exceeding 10, it becomes difficult to grasp overall characteristics. In contrast, when classifications are too few, classification itself cannot be performed properly.

\section{Results}

Figure 1 portrays simple guidelines based on the investigation described above. Here, values closer to Level 1 represent greater desirability of compactness provided in the district with respect to a low carbon society. The residential area of Level 3 corresponds to an overcrowded urban area in which the carbon load is low, but within which the residential environment and disaster prevention are not necessarily sufficient.

The transport environment load attributable to inhabitants from each district naturally depends on characteristics that peripheral districts have. By providing "global positioning" as an item in the simple guidelines, features that these districts possess in general can be described from a global perspective. 


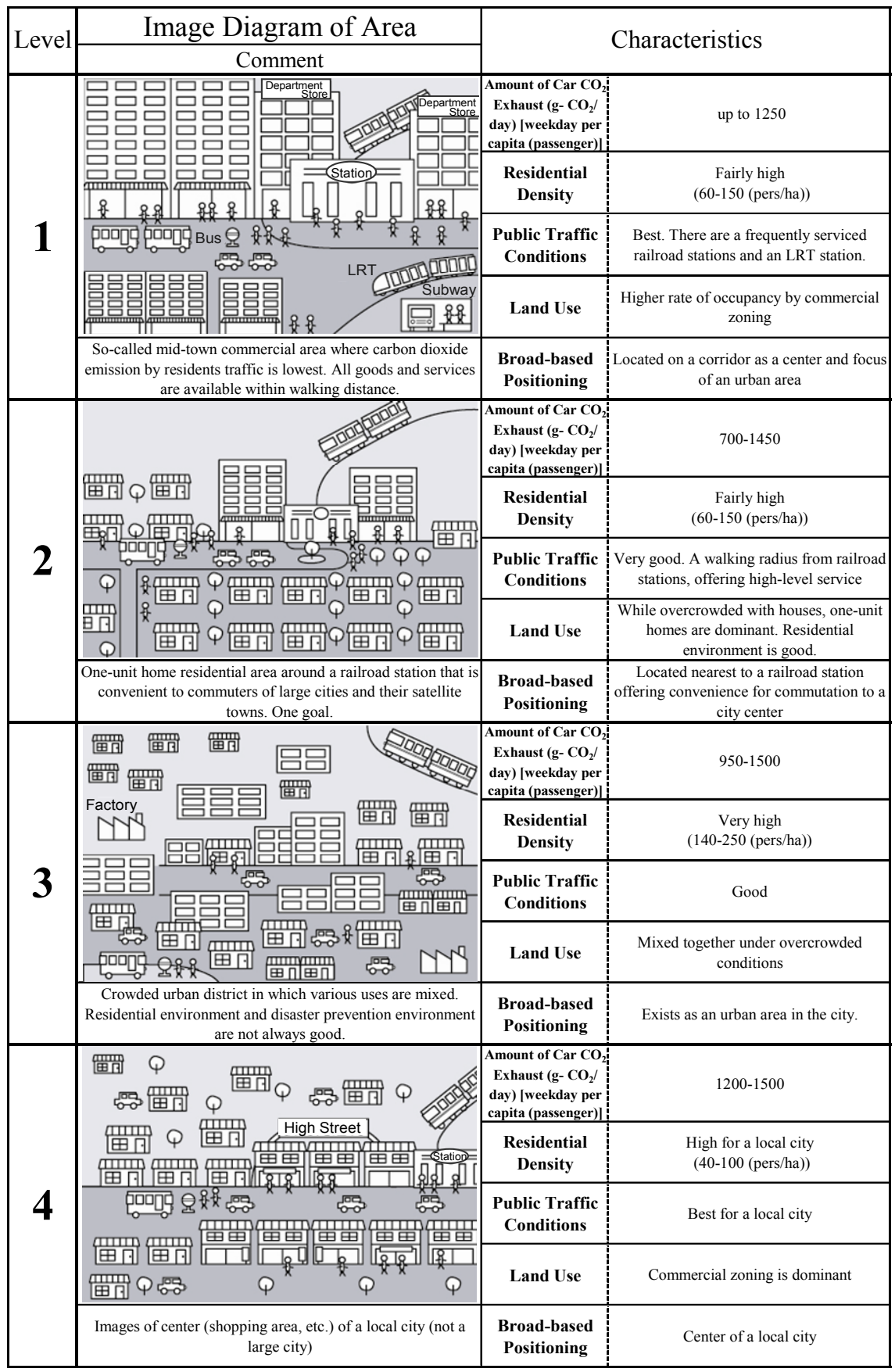

Figure 1: $\quad$ Results of preparing urban planning guidelines (simple edition) for achieving a low carbon society. 


\begin{tabular}{|c|c|c|c|}
\hline \multirow{2}{*}{ Level } & Image Diagram of Area & \multirow[b]{3}{*}{$\begin{array}{l}\text { Amount of } \mathrm{Car}^{-} \mathrm{CO}_{2} \\
\text { Exhaust (g- } \mathrm{CO}_{2} / \\
\text { day) [weekday per } \\
\text { capita (passenger)] }\end{array}$} & \multirow{2}{*}{ Characteristics } \\
\hline & Comment & & \\
\hline \multirow{6}{*}{5} & $\infty$ & & $1200-1950$ \\
\hline & 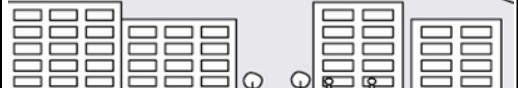 & $\begin{array}{c}\text { Residential } \\
\text { Density }\end{array}$ & $\begin{array}{c}\text { Very high } \\
(120-250(\text { pers/ha) })\end{array}$ \\
\hline & \multirow{3}{*}{ 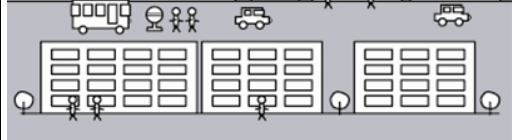 } & \multirow{2}{*}{$\begin{array}{c}\text { Public Traffic } \\
\text { Conditions }\end{array}$} & \multirow{2}{*}{ Good on a case-by-case basis. } \\
\hline & & & \\
\hline & & Land Use & $\begin{array}{l}\text { Comprising mid-to-high-rise housing and } \\
\text { condos }\end{array}$ \\
\hline & $\begin{array}{c}\text { Composed of unified mid-to-high-rise housing such as housing } \\
\text { complexes, condominiums }\end{array}$ & $\begin{array}{l}\text { Broad-based } \\
\text { Positioning }\end{array}$ & $\begin{array}{l}\text { Not necessarily located on a public } \\
\text { transport axis }\end{array}$ \\
\hline \multirow{5}{*}{6} & \multirow{5}{*}{$\begin{array}{c}\text { Mostly unified residential area with properly controlled land } \\
\text { use in the suburbs. }\end{array}$} & $\begin{array}{l}\text { Amount of } \mathrm{Car} \mathrm{CO}_{2} \\
\text { Exhaust (g- } \mathrm{CO}_{2} / \\
\text { day) [weekday per } \\
\text { capita (passenger)] }\end{array}$ & $1200-2200$ \\
\hline & & $\begin{array}{l}\text { Residential } \\
\text { Density }\end{array}$ & $\begin{array}{c}\text { Low } \\
(10-50 \text { (pers/ha) })\end{array}$ \\
\hline & & $\begin{array}{l}\text { Public Traffic } \\
\text { Conditions }\end{array}$ & Not good \\
\hline & & Land Use & $\begin{array}{l}\text { Density of land use overall the district is } \\
\text { low but sharp }\end{array}$ \\
\hline & & $\begin{array}{c}\text { Broad-based } \\
\text { Positioning }\end{array}$ & $\begin{array}{l}\text { Often deflected from a public } \\
\text { transportation axis. A historic settlement } \\
\text { sometimes becomes the core of the district. }\end{array}$ \\
\hline \multirow{5}{*}{7} & \multirow{4}{*}{ } & $\begin{array}{l}\text { Amount of } \mathrm{Car} \mathrm{CO}_{2} \\
\text { Exhaust (g- } \mathrm{CO}_{2} / \\
\text { day) [weekday per } \\
\text { capita (passenger)] }\end{array}$ & $1650-2500$ \\
\hline & & $\begin{array}{l}\text { Residential } \\
\text { Density }\end{array}$ & $\begin{array}{l}\text { Somewhat low } \\
(30-80 \text { (pers/ha)) }\end{array}$ \\
\hline & & $\begin{array}{l}\text { Public Traffic } \\
\text { Conditions }\end{array}$ & Not good \\
\hline & & Land Use & $\begin{array}{l}\text { Denser than Type } 9 \text { and Type } 10 \text {, but } \\
\text { thinner than Type } 2\end{array}$ \\
\hline & $\begin{array}{l}\text { Poorly planned suburban residential area such as mini } \\
\text { development }\end{array}$ & $\begin{array}{c}\text { Broad-based } \\
\text { Positioning }\end{array}$ & $\begin{array}{l}\text { Bus service is available; however, some } \\
\text { districts are deflected from a public } \\
\text { transportation axis }\end{array}$ \\
\hline \multirow{6}{*}{8} & & $\begin{array}{l}\text { Amount of } \mathrm{Car} \mathrm{CO}_{2} \\
\text { Exhaust (g- } \mathrm{CO}_{2} / \\
\text { day) [weekday per } \\
\text { capita (passenger)] }\end{array}$ & $1900-2900$ \\
\hline & 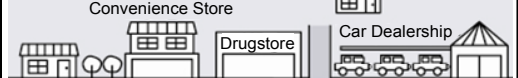 & $\begin{array}{l}\text { Residential } \\
\text { Density }\end{array}$ & $\begin{array}{l}\text { Low for a large city } \\
(30-100 \text { (pers/ha)) }\end{array}$ \\
\hline & ॠक & \multirow{2}{*}{$\begin{array}{c}\text { Public Traffic } \\
\text { Conditions }\end{array}$} & \multirow{2}{*}{$\begin{array}{l}\text { Bad. A district where road traffic is } \\
\text { dominant. }\end{array}$} \\
\hline & Eos & & \\
\hline & 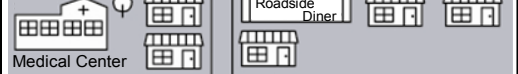 & Land Use & $\begin{array}{l}\text { Roadside type commerce along an urban } \\
\text { main road }\end{array}$ \\
\hline & $\begin{array}{l}\text { District where roadside type commercial facilities developed } \\
\text { along an urban main road are ramblingly located. }\end{array}$ & $\begin{array}{l}\text { Broad-based } \\
\text { Positioning }\end{array}$ & Deflected from a public transportation axis \\
\hline
\end{tabular}

Figure 2: Results of preparing urban planning guidelines (simple edition) for achieving a low carbon society. 


\begin{tabular}{|c|c|c|c|}
\hline \multirow{2}{*}{ Level } & Image Diagram of Area & \multicolumn{2}{|r|}{ Characteristics } \\
\hline & Comment & & \\
\hline \multirow{5}{*}{9} & \multirow{2}{*}{ 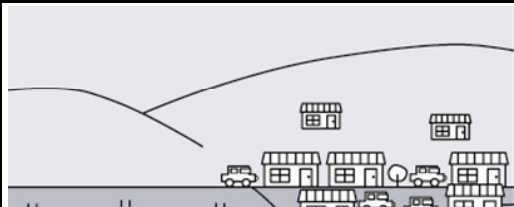 } & $\begin{array}{l}\text { Amount of } \mathrm{Car} \mathrm{CO}_{2} \\
\text { Exhaust (g- } \mathrm{CO}_{2} / \\
\text { day) [weekday per } \\
\text { capita (passenger)] }\end{array}$ & $2400-2900$ \\
\hline & & $\begin{array}{l}\text { Residential } \\
\text { Density }\end{array}$ & $\begin{array}{c}\text { Low } \\
(20-60(\text { pers/ha) })\end{array}$ \\
\hline & ' & $\begin{array}{c}\text { Public Traffic } \\
\text { Conditions }\end{array}$ & Rather bad \\
\hline & $" 11$ & Land Use & $\begin{array}{l}\text { A one-unit home residential area where } \\
\text { land use density is low }\end{array}$ \\
\hline & $\begin{array}{l}\text { A one-unit home residential area located as an extension of an } \\
\text { urban area. Based on car transport. }\end{array}$ & $\begin{array}{l}\text { Broad-based } \\
\text { Positioning }\end{array}$ & $\begin{array}{l}\text { Deflected from an urban area public } \\
\text { transportation axis; isolated }\end{array}$ \\
\hline \multirow{5}{*}{10} & \multirow{2}{*}{ 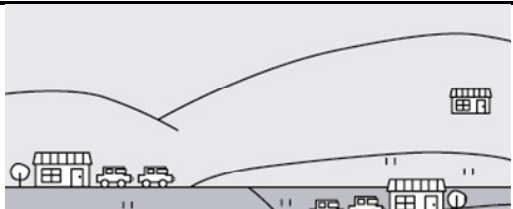 } & $\begin{array}{l}\text { Amount of } \mathrm{Car} \mathrm{CO}_{2} \\
\text { Exhaust (g- } \mathrm{CO}_{2} / \\
\text { day) [weekday per } \\
\text { capita (passenger)] }\end{array}$ & 2600 and over \\
\hline & & $\begin{array}{l}\text { Residential } \\
\text { Density }\end{array}$ & $\begin{array}{c}\text { Very low } \\
\text { (less than } 20 \text { (pers/ha)) }\end{array}$ \\
\hline & 1111 & $\begin{array}{c}\text { Public Traffic } \\
\text { Conditions }\end{array}$ & None \\
\hline & "1 & Land Use & $\begin{array}{l}\text { One-unit homes are scattered in farmland. } \\
\text { No land use planning done initially. }\end{array}$ \\
\hline & $\begin{array}{l}\text { A disorganized one-unit home located at the edge (in the } \\
\text { mountain forest, field) of a local city. Long-distance driving is } \\
\text { required for residents. }\end{array}$ & $\begin{array}{l}\text { Broad-based } \\
\text { Positioning }\end{array}$ & $\begin{array}{l}\text { Completely isolated from the urban area } \\
\text { structure }\end{array}$ \\
\hline
\end{tabular}

Figure 3: Results of preparing urban planning guidelines (simple edition) for achieving a low carbon society.

\section{Conclusion}

Using such indexes, we expect that each citizen, even if not a specialist, can measure and assess actual transport environmental loads in a familiar district (town) and regard its compactness, thereby deepening understanding of the district's sustainable development.

\section{Acknowledgements}

We are grateful for the cooperation of Kiuchi Chiho of Nikken Sekkei Research Institute for drawing work on the guidelines. We would like to express our gratitude for a Grant-in-Aid for Scientific Research (19360231 and 21320157), which supported our study.

\section{References}

[1] Taniguchi, M., Matsunaka, R. and Nakamichi, K., A time-series analysis of the relationship between urban layout and automobile reliance: have cities 
shifted to integration of land use and transport? (Ed. by Brebbia, C.), Urban Transport XIV, pp. 415-424, WIT Press, 2008.

[2] Echenique, M., Hargreaves, A. and Mitchell, G., Spatial planning, sustainability and long-run trends, Town and Country Planning, Vol.78, No.9, pp. 380-385, 2009.

[3] Taniguchi, M. and Ikeda, T., The compact city as a means of reducing reliance on the car: A model-based analysis for a sustainable urban layout, (Ed. by Williams, K.), Spatial planning, urban form and sustainable transport, Ashgate, pp. 139-150, 2005.

[4] Taniguchi, M., Matsunaka, R. and Nakamichi, K., A pictorial encyclopedia of residential zones in Japan, - For sustainable urban planning -, Gihodo, 2007. (in Japanese) 